\begin{tabular}{|lcl}
\hline REVISTA & NARRATIVAS \\
DA \\
FUNDARTE
\end{tabular}

\title{
O TEMPO DO BRINCAR: \\ NARRATIVAS VISUAIS A PARTIR DE EXPERIÊNCIA ETNOGRÁFICA
}

Marina Di Napoli Pastore

DOI: $10.19179 / 2319-0868.796$ etnográfica. Revista da FUNDARTE. Montenegro, p.01-18, ano 26, no 42, julho/setembro de 2020.

Disponível em: http://.seer.fundarte.rs.gov.br/index.php/RevistadaFundarte/index> 30 de setembro de 2020 


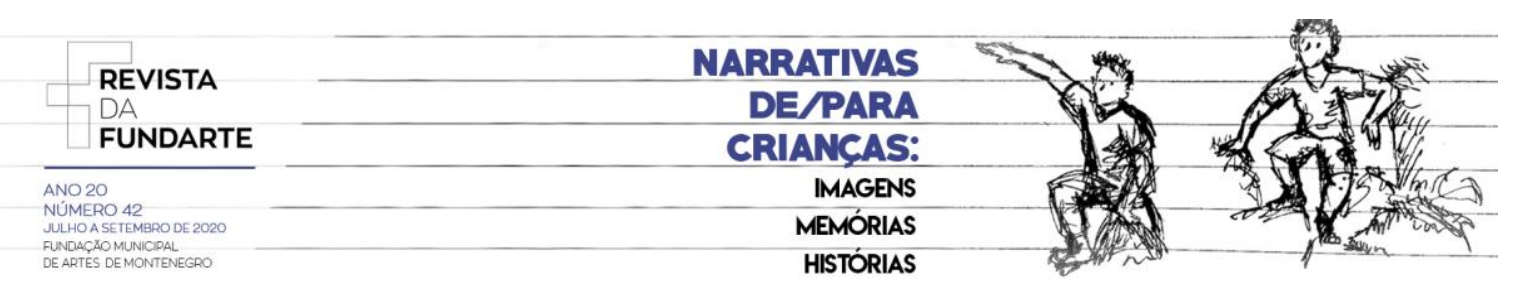

\section{O TEMPO DO BRINCAR: \\ NARRATIVAS VISUAIS A PARTIR DE EXPERIÊNCIA ETNOGRÁFICA}

Marina Di Napoli Pastore ${ }^{1}$

Resumo: Em África, as crianças e imagens que aparecem com maior frequência são as associadas às faltas, negatividade e explorações diversas. Como dizia Cascudo (2001, p. 229), "raro é o registro do viajante europeu sobre o brinquedo do menino africano. Preocupam-se todos em fixar aspectos sociais, soberanos, corte, protocolo, superstições, produtos, escravaria, guerras, ângulos antropométricos, religiões. Quem se vai preocupar em ver como brincava o negrinho? E como ele gastava e ocupava seu tempo é ausência nos grandes livros (...)". Este ensaio traz imagens feitas com crianças e por elas, em momentos do cotidiano, em que as potências e as trocas ganhavam contornos e espaços, possibilitando outras narrativas para suas histórias.

Palavras-chave: Crianças; Brincar; Fotografia; Moçambique.

\section{LE TEMPS DE JEU: \\ RÉCITS VISUELS A PARTIR DE L'EXPÉRIENCE ETHNOGRAPHIQUE}

Résume: En Afrique, les enfants et les images qui apparaissent le plus souvent sont associés à des fautes, à la négativité et à diverses exploitations. Comme le dit Cascudo (2001, p. 229), "il est rare que le voyageur européen enregistre le jouet du garçon africain. Ils sont tous concernés par la fixation sociale, souveraine, coupe, protocole, superstitions, produits, esclavage, guerres, angles anthropométriques, religions. Qui va s'inquiéter de regarder le petit enfant noir jouer? Et comment il a passé et occupé son temps, c'est l'absence dans les grands livres (...) ". Cet essai apporte des images créées avec les enfants et par eux, dans des moments de la vie quotidienne, dans lesquels puissances et échanges ont gagné des contours et des espaces, permettant ainsi à d'autres récits de raconter leurs histoires.

Mots-clés: Enfants; Joue; La photographie; Mozambique.

\section{TIME OF PLAY: VISUALS NARRATIVES FROM OF ETHNOGRAPHIC EXPERIENCE}

Abstract: In Africa, chidren and their images appears associated with faults, negativity and many explorations. As Cascudo (2001, p. 229) said, "It is rare that the European traveler registers the African boy's toy. They are all anxious to fix social, sovereign, cut, protocol, superstitions, products, slavery, wars, anthropometric angles, religions. Who is going to worry about watching the little black kid play? And how he spent and occupied his time is absence in the great books (...) ". his essay brings images made with children and by them, in moments of daily life, in which powers and exchanges gained contours and spaces, allowing other narratives for their stories.

Keywords: Children; To play; Fotography; Mozambique.

\footnotetext{
${ }^{1}$ Doutora em Terapia Ocupacional pela Universidade Federal de São Carlos. Doutoranda em mobilidade estudantil - edital PDSE CAPES 47/2018. Mestre em Terapia Ocupacional Universidade Federal de São Carlos. Pesquisadora Núcleo Amanar - Casa das Áfricas. Colaboradora no Projeto Munthi Wa Swivanana (Moçambique).
}

PASTORE, Marina Di Napoli. O tempo do brincar: narrativas visuais a partir de experiência etnográfica. Revista da FUNDARTE. Montenegro, p.01-18, ano 26, no 42, julho/setembro de 2020.

Disponível em: http://.seer.fundarte.rs.gov.br/index.php/RevistadaFundarte/index> 30 de setembro de 2020 


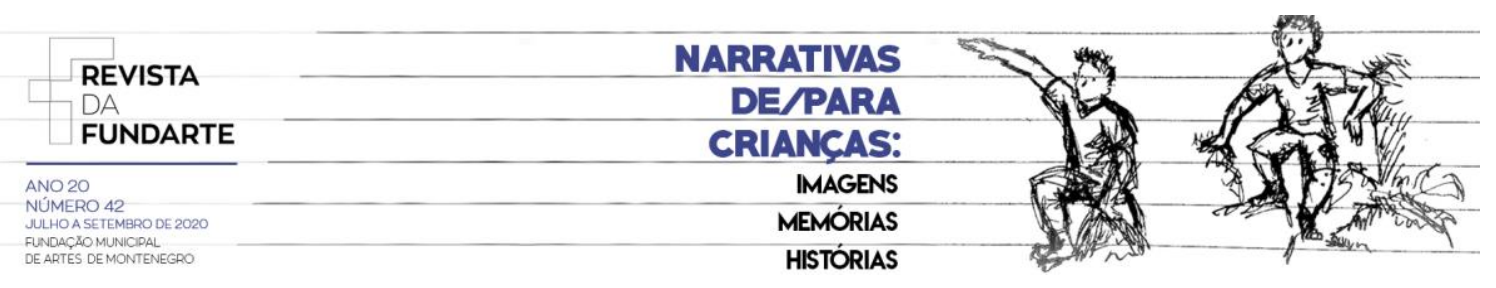

\section{Introdução}

Baseado em uma pesquisa etnográfica realizada entre os anos de 2014 e 2018 na cidade da Matola, no bairro da Matola A, em Maputo, Moçambique, este ensaio, que se arrisca fotográfico, é parte da pesquisa doutoral sobre a temática das infâncias e crianças ao sul de Moçambique: saberes infantis e produções culturais. A vivência etnográfica se deu no dia-a-dia das crianças, no espaço-tempo da casa, escola e convivência no bairro. Para tal estudo, a pesquisadora morou no bairro, na casa das crianças, e participou das atividades, tarefas e momentos de brincadeira em que the foram permitidos estar e partilhar trocas, interações e vivências, respeitando e conhecendo as dinâmicas sociais, culturais, de valores e relacionais. Conhecer a visão das crianças sobre o mundo que as rodeia, através de uma pesquisa etnográfica, possibilitou viabilizar dispositivos para "encarar as vidas das crianças estudadas como uma realidade complexa, marcada por luzes e sombras, potencialidades e criticidades" (COLLONA, 2012, p. 4).

Quais são, portanto, as implicações de se introduzir na vida cotidiana de pessoas de uma outra cultura? Como estabelecer a relação de proximidade sem esquecer-se como diverso? Para isto, foi necessário aceitar o desafio de arriscar-se num lugar outro, no qual pesquisador e pesquisado formaram uma parceria dialógica, numa construção diária e processual de relação e vínculo, sem perder de vista que o processo de construção de conhecimento é "uma realidade participada e partilhada" (SOARES; SARMENTO; TOMÁS, 2005). No caso da etnografia com crianças, esse desafio se tornou, para mim, ainda maior: como relacionar o meu mundo adulto e de quem vem de fora, com o mundo delas, de quem está dentro?

Ao trabalhar com as crianças como atores sociais plenos, assume-se, também, suas competências para a formulação de interpretações sobre seus mundos e modos de vida, e como reveladores das realidades sociais nas quais se inserem. Optei por realizar a pesquisa de campo no bairro da Matola A, e trabalhar com cinco crianças; esse número foi escolhido para que assim pudesse ter uma

PASTORE, Marina Di Napoli. O tempo do brincar: narrativas visuais a partir de experiência etnográfica. Revista da FUNDARTE. Montenegro, p.01-18, ano 26, № 42, julho/setembro de 2020.

Disponível em: http://seer.fundarte.rs.gov.br/index.php/RevistadaFundarte/index> 30 de setembro de 2020 


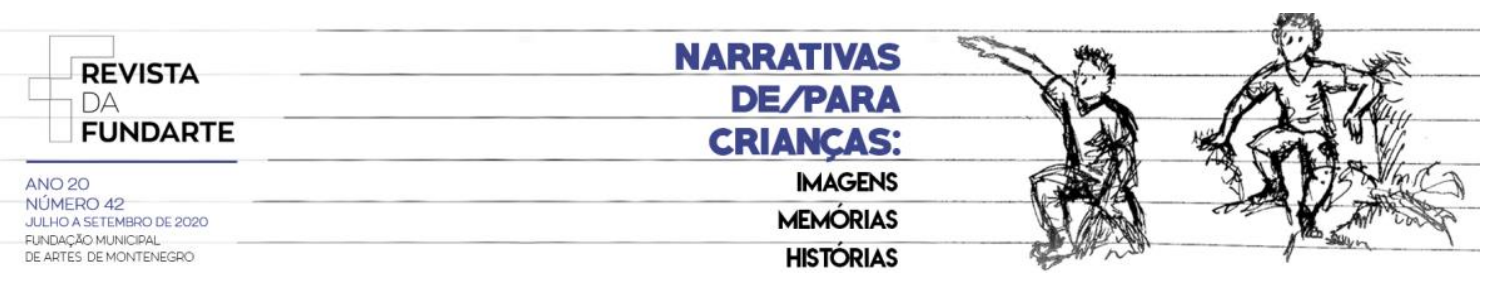

vivência mais aprofundada e detalhada sobre o dia-a-dia delas, sendo capaz de captar os símbolos e significados de uma maneira mais precisa - porém, o envolvimento e convivência com as outras crianças, nos espaços em que tive acesso, como a escola e mesmo as ruas do bairro, não foram excluídos; eles serviram, também, para ampliar e clarear algumas experiências e suas possíveis interpretações.

O trabalho de campo forma, então, um elemento central para acessar a produção do sentido simbólico e de inscrição das crianças do bairro Matola $A$, participantes deste estudo. Foi possível reconhecer, em suas atividades e responsabilidades, a formação da pessoa moçambicana que, pautada na divisão social do trabalho, encontra nas crianças maneiras possíveis de criar ferramentas de trocas e aprendizagem que são passadas entre gerações no cuidado com o outro, como no do irmão mais velho com o mais novo ou na prática das tarefas domésticas, além das relações entre pares e descobertas nos momentos do brincar, observados em passagens distintas do dia-a-dia, em que a imaginação é parte fundamental na criação das brincadeiras e na co-produção dos brinquedos, como nas pipas, bolas, bonecos, garrafas, pneus, entre outros.

O modo como as crianças produzem seus brinquedos, a partir de materiais encontrados pelo bairro, e como denotam as influências e percepções das culturas que as rodeiam, permitem que enxerguemos para além do que nos é dito: é preciso permitir que as infâncias e crianças possam ocorrer, no espaço-tempo determinados e contextualizados. As imagens trazidas são uma construção coletiva de 5 anos de trabalho e parceria firmada com as crianças da Matola A. São diversas narrativas produzidas, de momentos vivenciados e partilhados do dia-a-dia com as crianças, em seus lugares de pertencimento e de significação. É um olhar para as crianças a partir dos seus olhares e se baseia a partir da escuta de suas vozes, importantes no desenvolvimento desta e de tantas outras narrativas com as quais venho trabalhando, numa co-construção e co-produção dos relatos e experiências da vida cotidiana da infância naquele contexto, permitidos pelo trabalho etnográfico. 0 etnográfica. Revista da FUNDARTE. Montenegro, p.01-18, ano 26, no 42, julho/setembro de 2020.

Disponível em: http://.seer.fundarte.rs.gov.br/index.php/RevistadaFundarte/index> 30 de setembro de 2020 


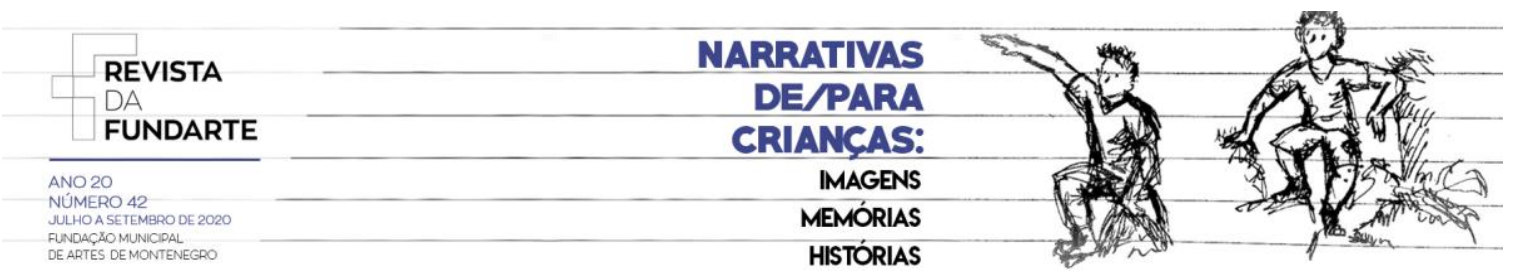

tempo da pesquisa se deu no espaço aberto, do correr, de observar, de estar junto e do brincar.

A câmera fotográfica foi, entre outros, instrumento de comunicação e de construção comum do olhar sobre o mundo da experiência significativa. A liberdade de seu manejo pelas crianças em sua operação e nas fotos que tiraram, possibilitou trocas em exercício da prática etnográfica de maior vinculação, num caminho de uma pesquisa (com)partilhada e porta para os entendimentos múltiplos e diversos. Assim, compreende-se a importância do processo de retorno e de restituição das fotografias, veiculando vínculos e reciprocidade entre as pessoas participantes da pesquisa.

Construído junto às e com as crianças, em espaço de tempo longitudinal, as fotos, bem como o texto ${ }^{2}$ que narra parte dessas vivências é uma produção realizada ao longo destes anos, num processo de pesquisa, encontro, ressignificações, partilha, aprendizado e afeto. Nosso convite ao brincar, ao sensível e a enxergar o belo para além das falhas e imagens adversas; resistir, persistir e não desistir das potencialidades das infâncias e das belezas das diversas crianças.

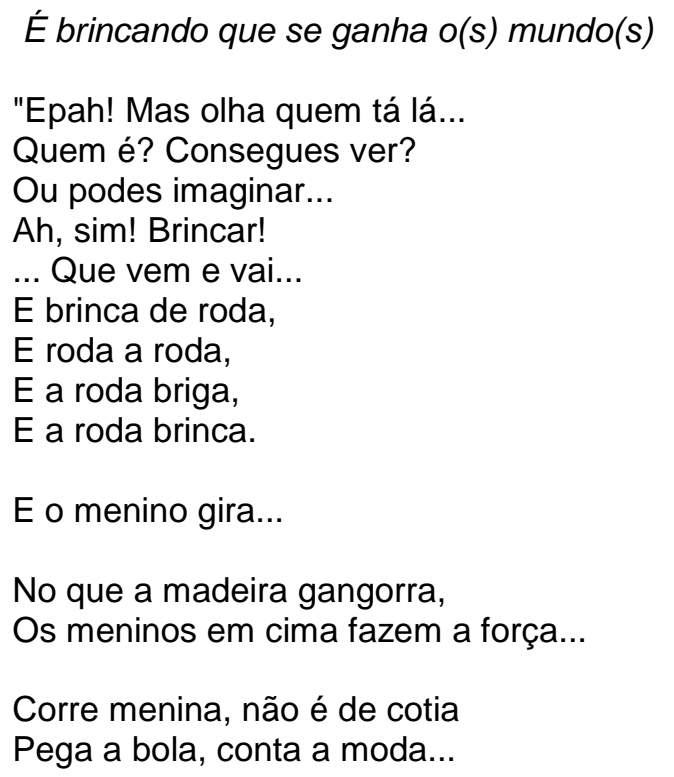

${ }^{2}$ Trecho de diário de campo disponível no site http://serestrangeiromulungu.blogspot.com.br

PASTORE, Marina Di Napoli. O tempo do brincar: narrativas visuais a partir de experiência etnográfica. Revista da FUNDARTE. Montenegro, p.01-18, ano 26, no 42, julho/setembro de 2020.

Disponível em: http://.seer.fundarte.rs.gov.br/index.php/RevistadaFundarte/index> 30 de setembro de 2020 


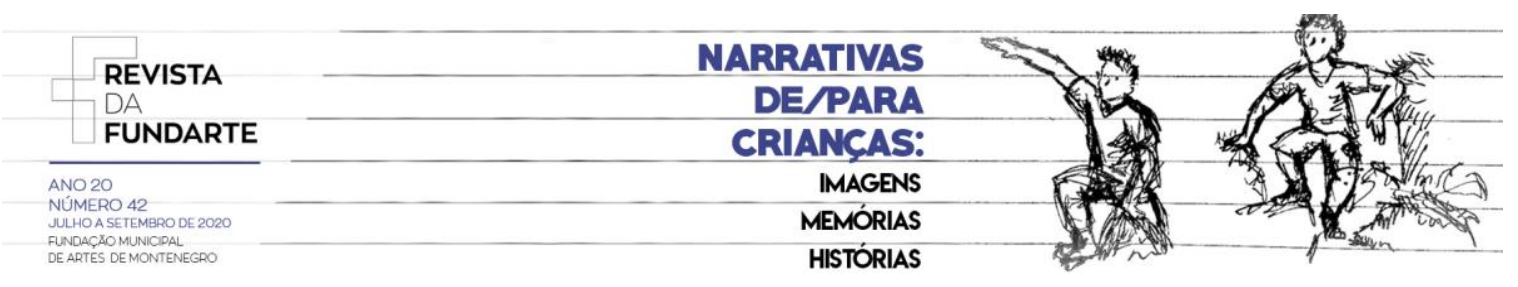

Corre pra lá, corre pra cá.

E não se deixa de brincar"

(Marina Di Napoli Pastore)

O poema acima ilustra um pouco dos dias em campo. Já diziam as crianças: para acontecer, é preciso estar. As brincadeiras, segundo elas, vão acontecendo e criando forma no estar, no presente do momento em que ocorrem, no aqui e agora daquele instante. E pode ser corda, carro, pular do telhado. Tem aquelas que brincam de queimada, contam sapatos, fazem corridas de roda, cavam a areia, acham uma caverna. Os meninos logo pegam a madeira e inventam a gangorra. Corre, abraça, volta a jogar. São diversas brincadeiras, diferentes modos de brincar. Ainda vão insistir que aqui não se brinca? Félix era claro "brincamos, e muito, aqui. Mulungu ${ }^{3}$ não vê isso. Sorte que és nossa". Haverá algum momento que deixaremos de normatizar ou agrupar as infâncias e crianças em um só lugar? O que vemos é diferente: são muitas, diversas - são crianças, infâncias, vivências, prazeres...

No momento da distração, reparo ao redor. E quem vem chegando? É ele, novamente o brincar...

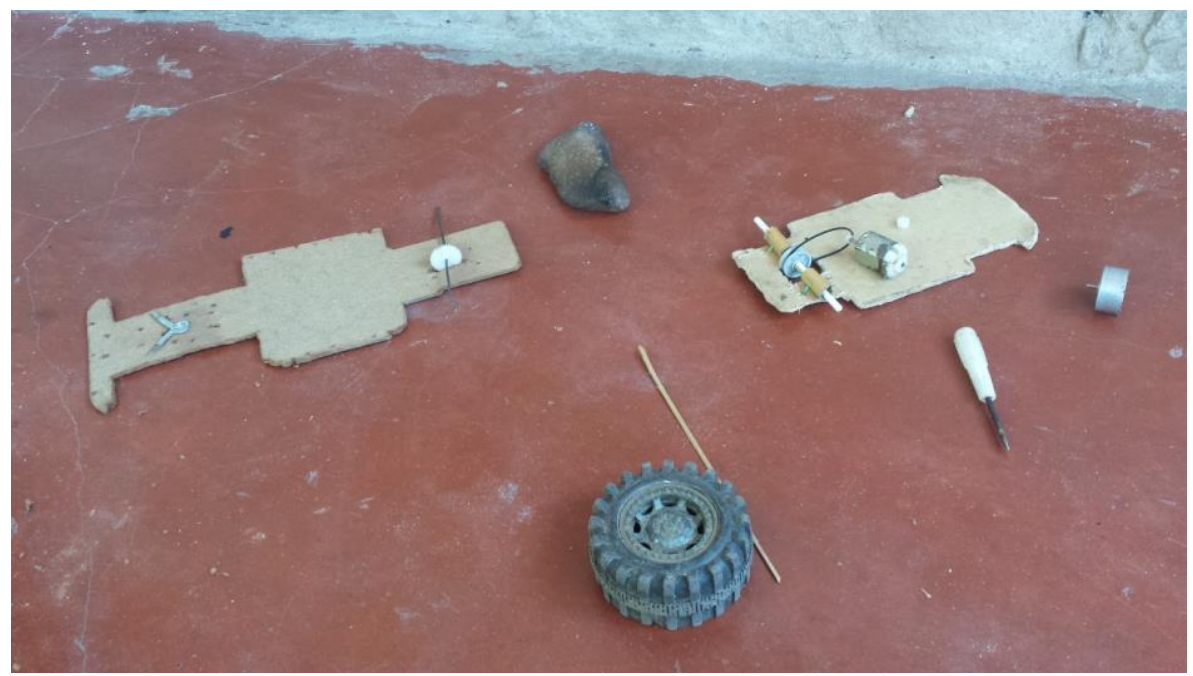

O juntar "lixo" (por Félix e Manelito)

\footnotetext{
${ }^{3}$ Termo em changana, língua local, que significa "branco" (etnia branca).
} 


\begin{tabular}{|l} 
REVISTA \\
DA \\
FUNDARTE
\end{tabular}

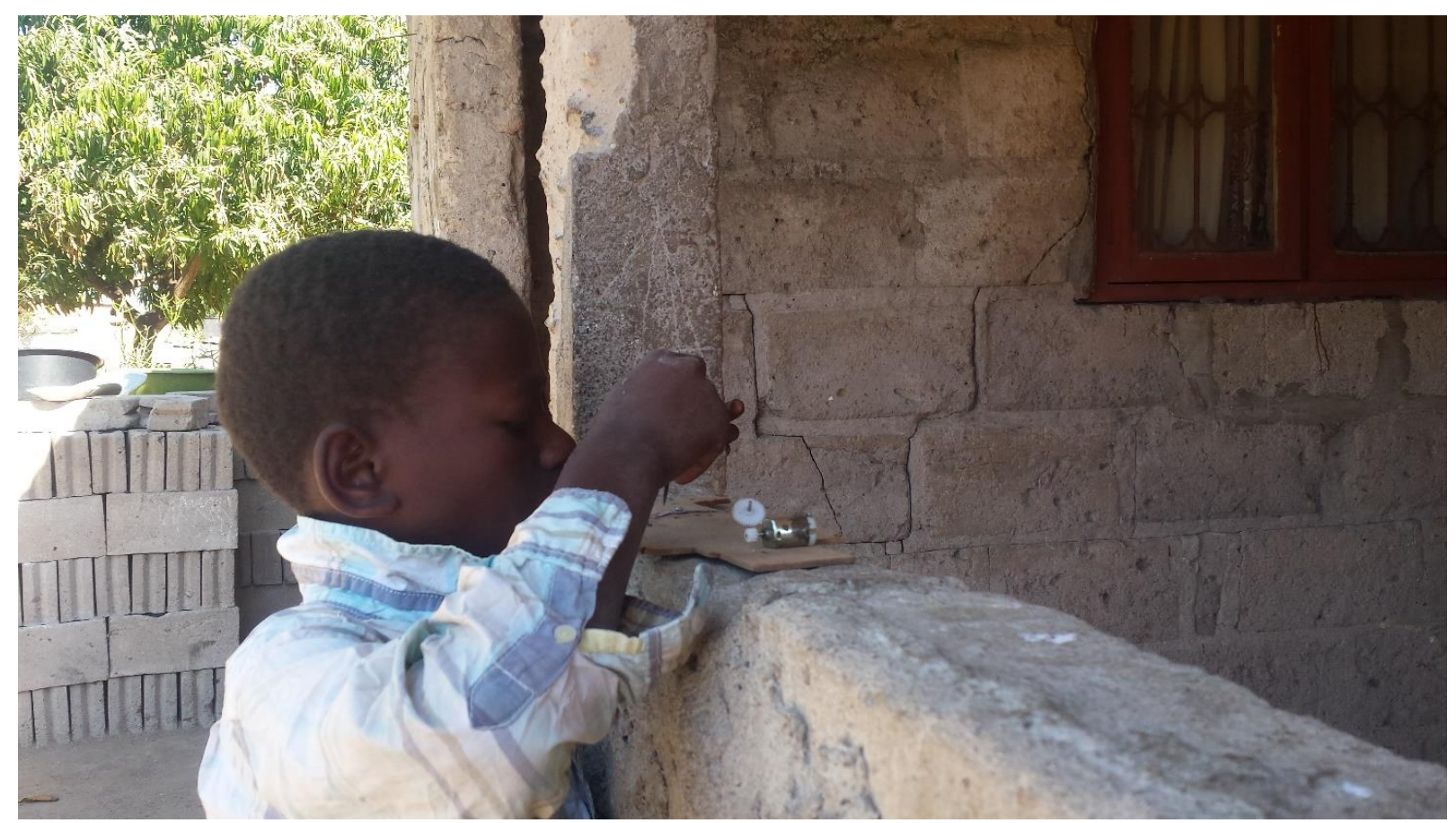

Olha lá (por Manelito)

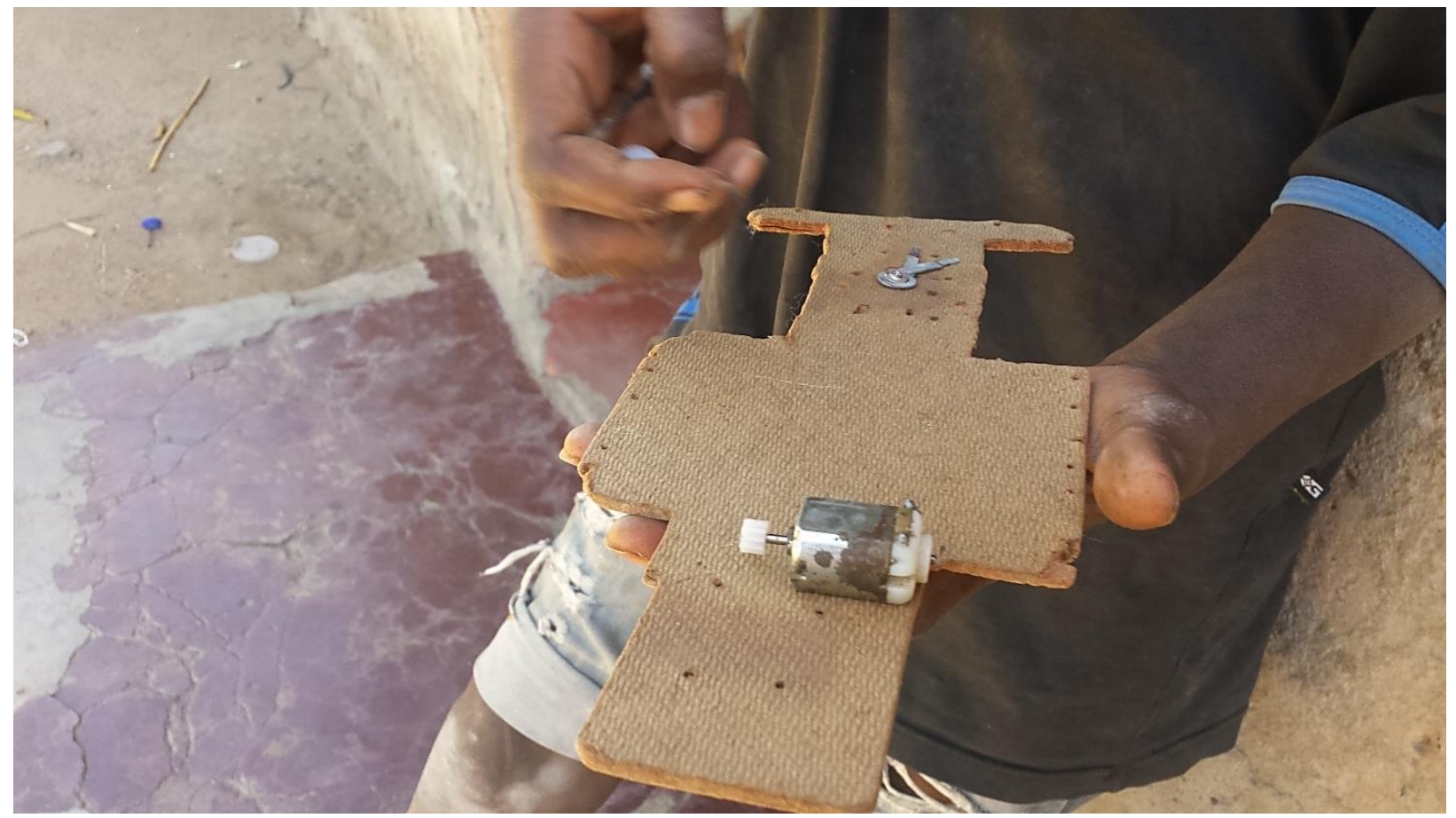

Essa é a base (por Félix)

PASTORE, Marina Di Napoli. O tempo do brincar: narrativas visuais a partir de experiência etnográfica. Revista da FUNDARTE. Montenegro, p.01-18, ano 26, nำ 42, julho/setembro de 2020.

Disponível em: http://.seer.fundarte.rs.gov.br/index.php/RevistadaFundarte/index> 30 de setembro de 2020 


\begin{tabular}{|l} 
REVISTA \\
DA \\
FUNDARTE
\end{tabular}

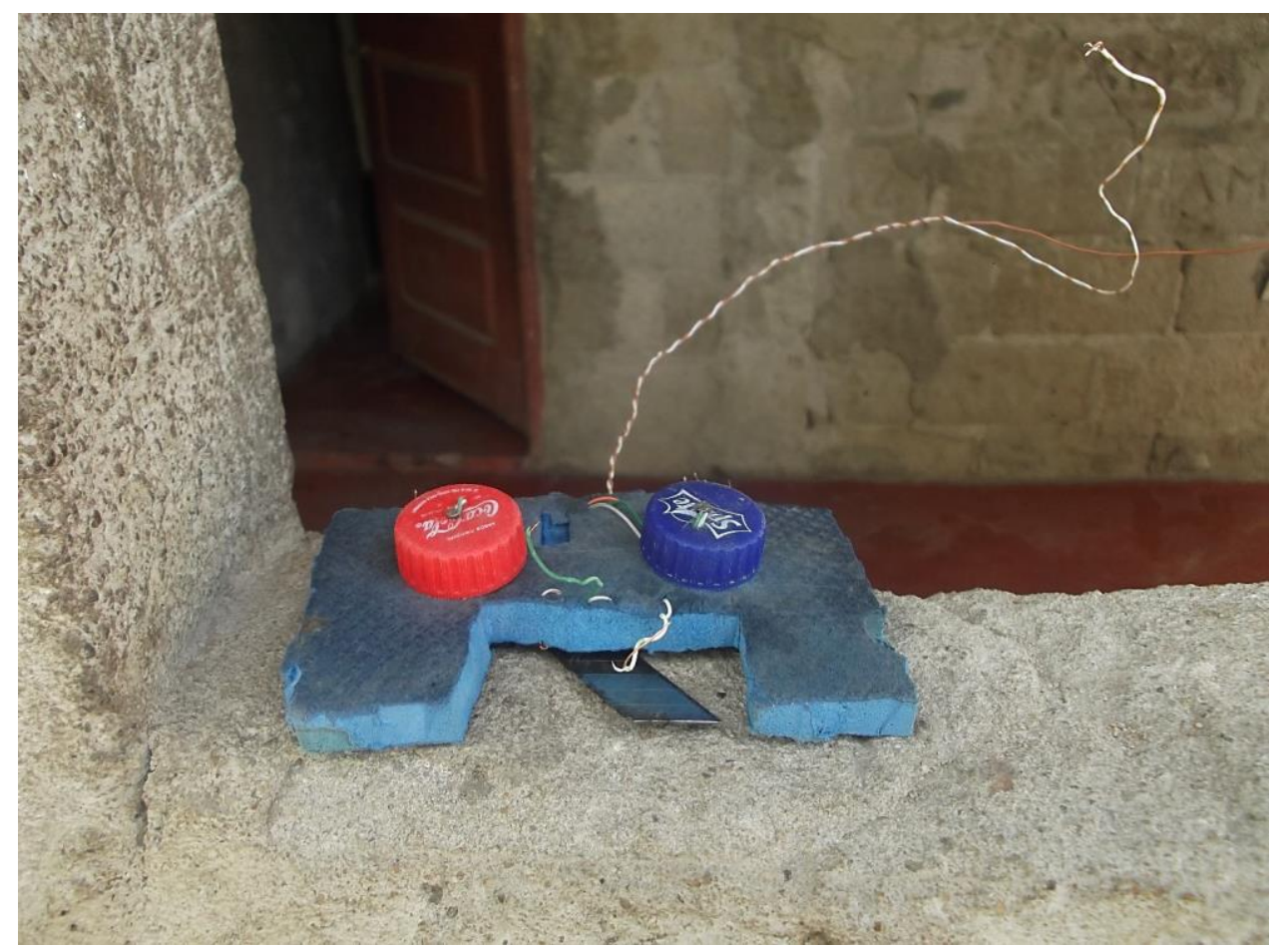

Controle do carro (por Félix e Manelito)

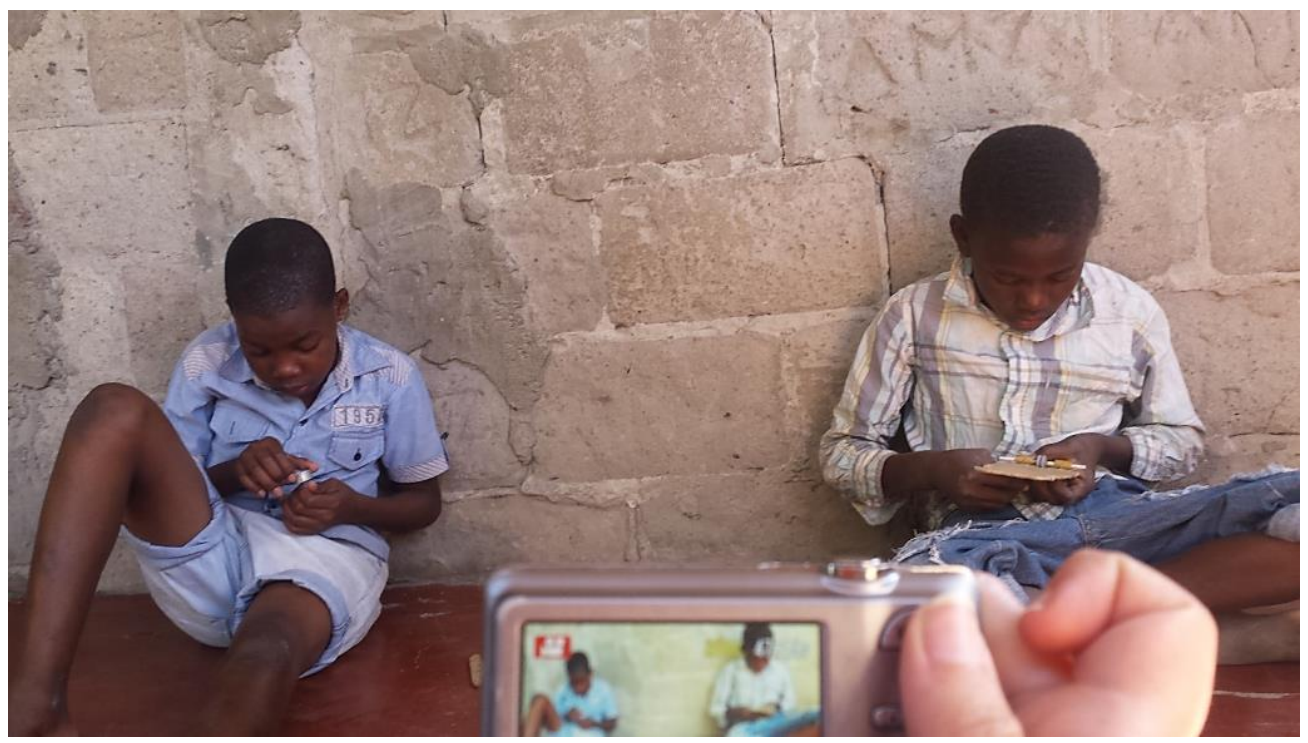

Entre trocas e construções (por Marina)

Juntam-se as peças daqui, pega "lixo" de lá...

-Vem! A gente te ensinar a montar! Hás de ver o que vai virar...

PASTORE, Marina Di Napoli. O tempo do brincar: narrativas visuais a partir de experiência etnográfica. Revista da FUNDARTE. Montenegro, p.01-18, ano 26, oㅡ 42, julho/setembro de 2020.

Disponível em: http://.seer.fundarte.rs.gov.br/index.php/RevistadaFundarte/index> 30 de setembro de 2020 


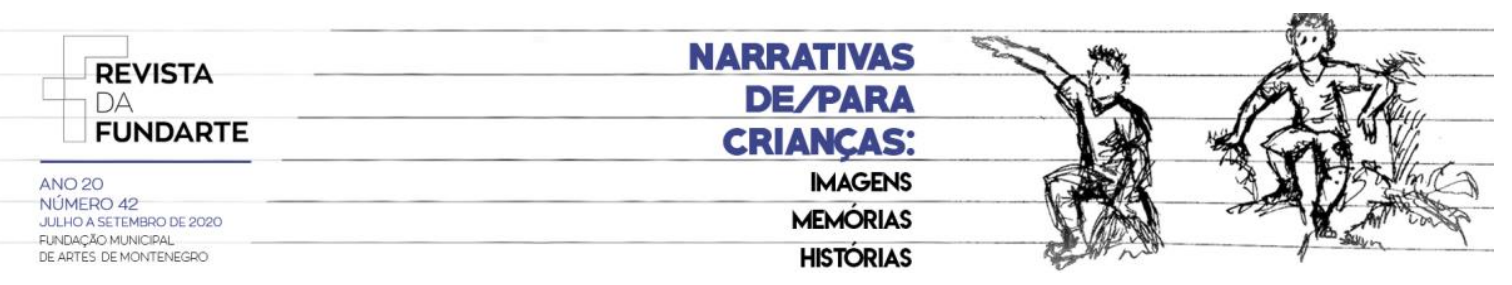

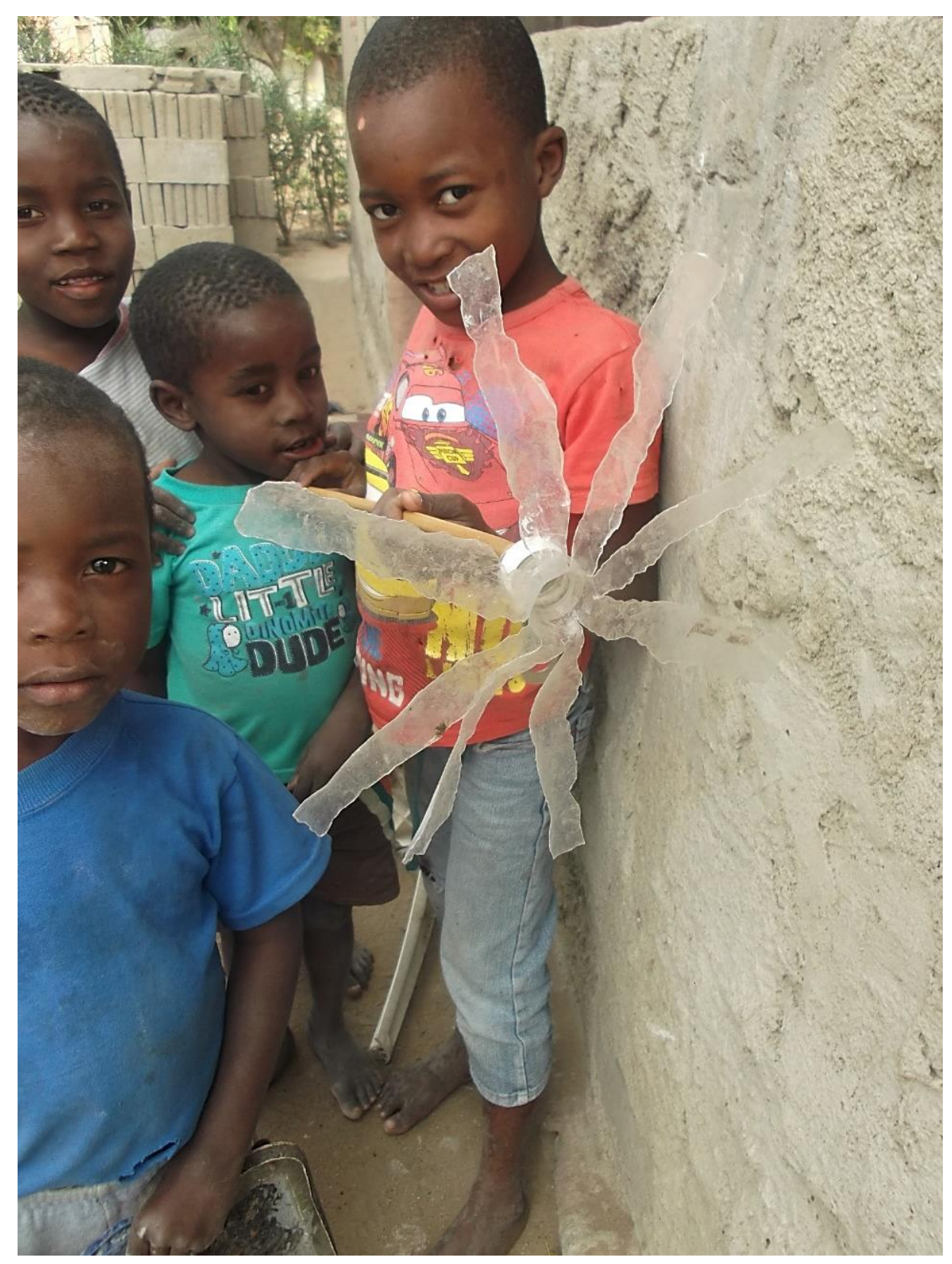

Avião (por Daimo)

E se deixar a imaginação liberar, como será?

PASTORE, Marina Di Napoli. O tempo do brincar: narrativas visuais a partir de experiência etnográfica. Revista da FUNDARTE. Montenegro, p.01-18, ano 26, no 42, julho/setembro de 2020.

Disponível em: http://.seer.fundarte.rs.gov.br/index.php/RevistadaFundarte/index> 30 de setembro de 2020 

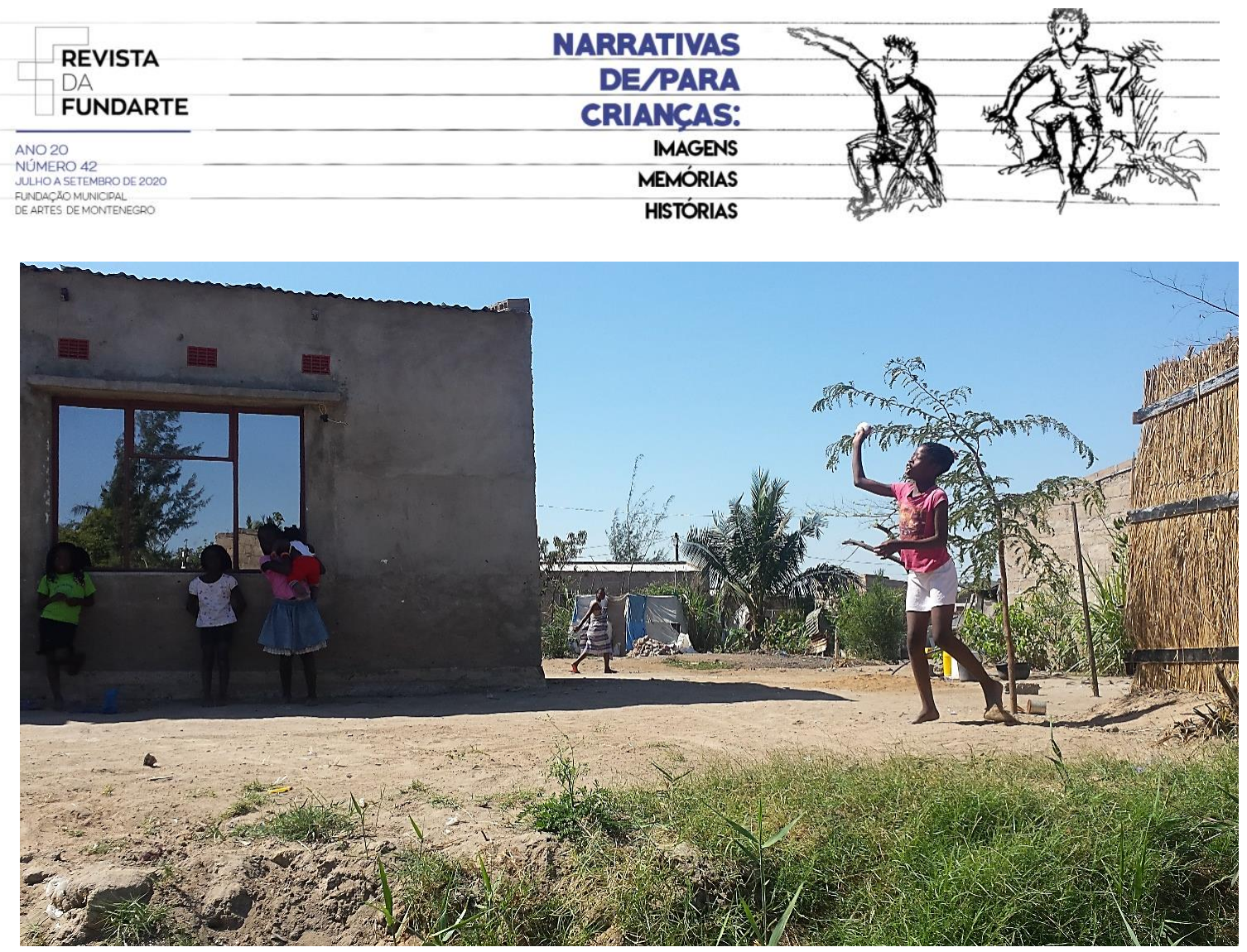

Queimada (por Marina)

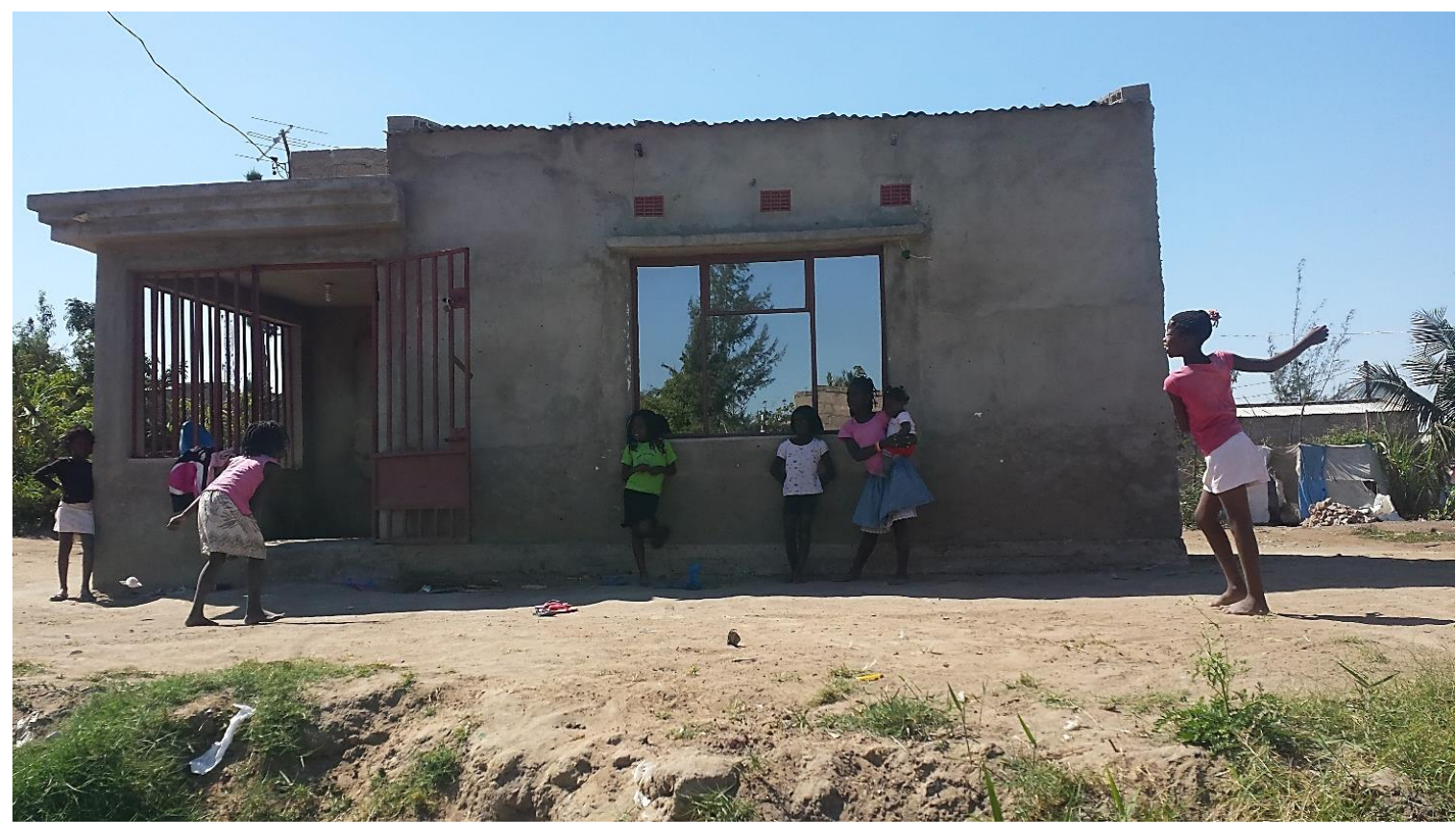

Jogando de brincar (por Samira)

Deixa correr! Deixa brincar! Quem sabe, deixa lá experimentar...

PASTORE, Marina Di Napoli. O tempo do brincar: narrativas visuais a partir de experiência etnográfica. Revista da FUNDARTE. Montenegro, p.01-18, ano 26, oㅡ 42, julho/setembro de 2020.

Disponível em: http://.seer.fundarte.rs.gov.br/index.php/RevistadaFundarte/index> 30 de setembro de 2020 


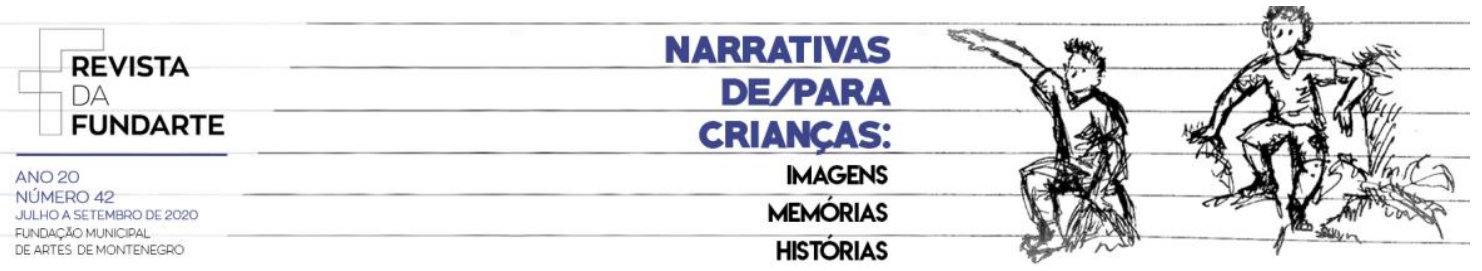

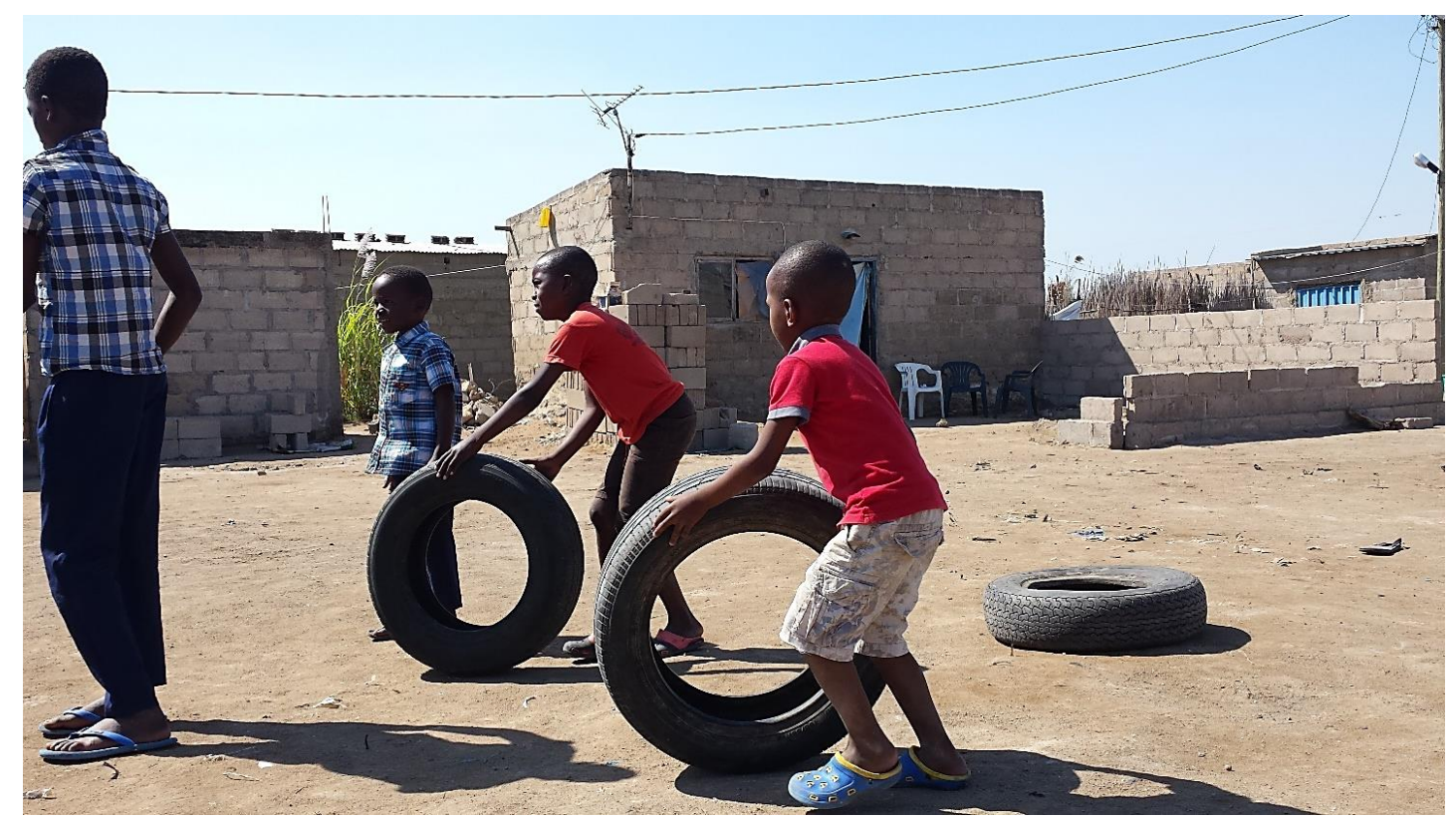

Corrida de rodas (por Januar)

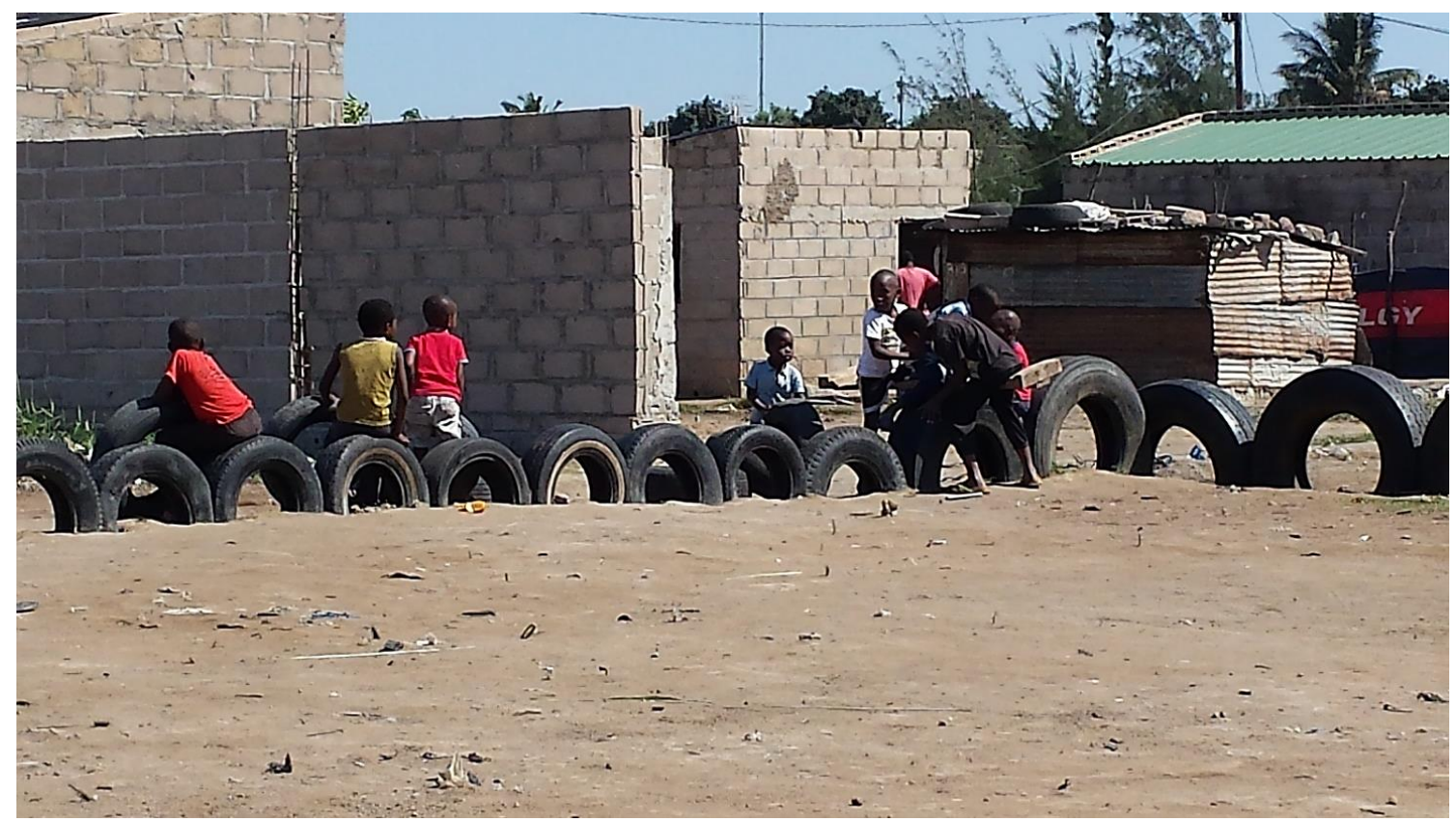

A equilibrar na madeira (por Januar) mundo...

Vai saber que rir é bom, que brincar faz parte e que ser criança é ganhar o PASTORE, Marna Di Napoli O tempo do brincar: narrativas visuais a partir de experiencia PASTORE, Marina Di Napoli. O tempo do brincar: narrativas visuais a partir de experiência etnográfica. Revista da FUNDARTE. Montenegro, p.01-18, ano 26, oㅡ 42, julho/setembro de 2020.

Disponível em: http://.seer.fundarte.rs.gov.br/index.php/RevistadaFundarte/index> 30 de setembro de 2020 

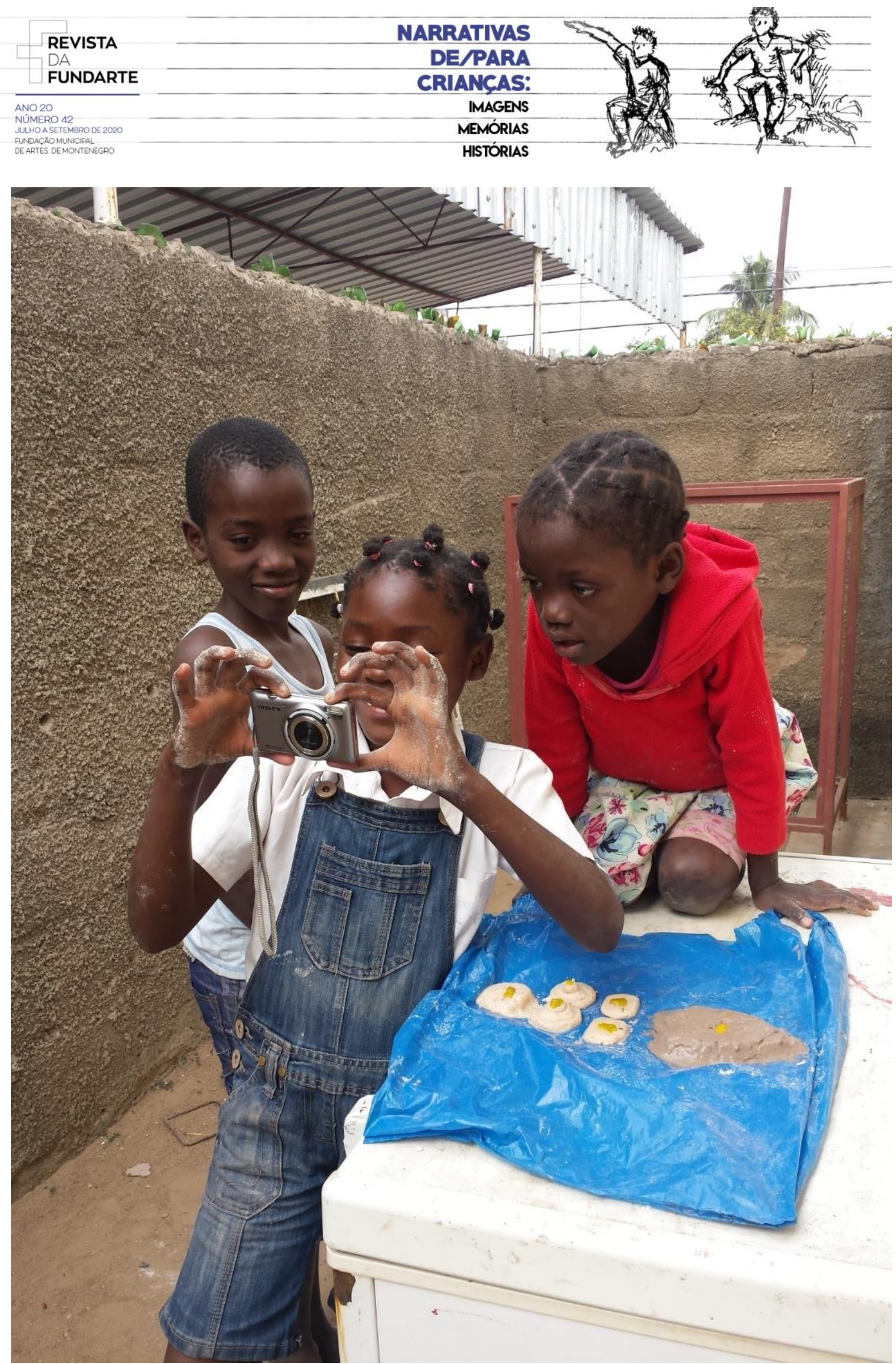

Fotografando caretas (por Marina)

PASTORE, Marina Di Napoli. O tempo do brincar: narrativas visuais a partir de experiência etnográfica. Revista da FUNDARTE. Montenegro, p.01-18, ano 26, oㅡ 42, julho/setembro de 2020.

Disponível em: http://.seer.fundarte.rs.gov.br/index.php/RevistadaFundarte/index> 30 de setembro de 2020 

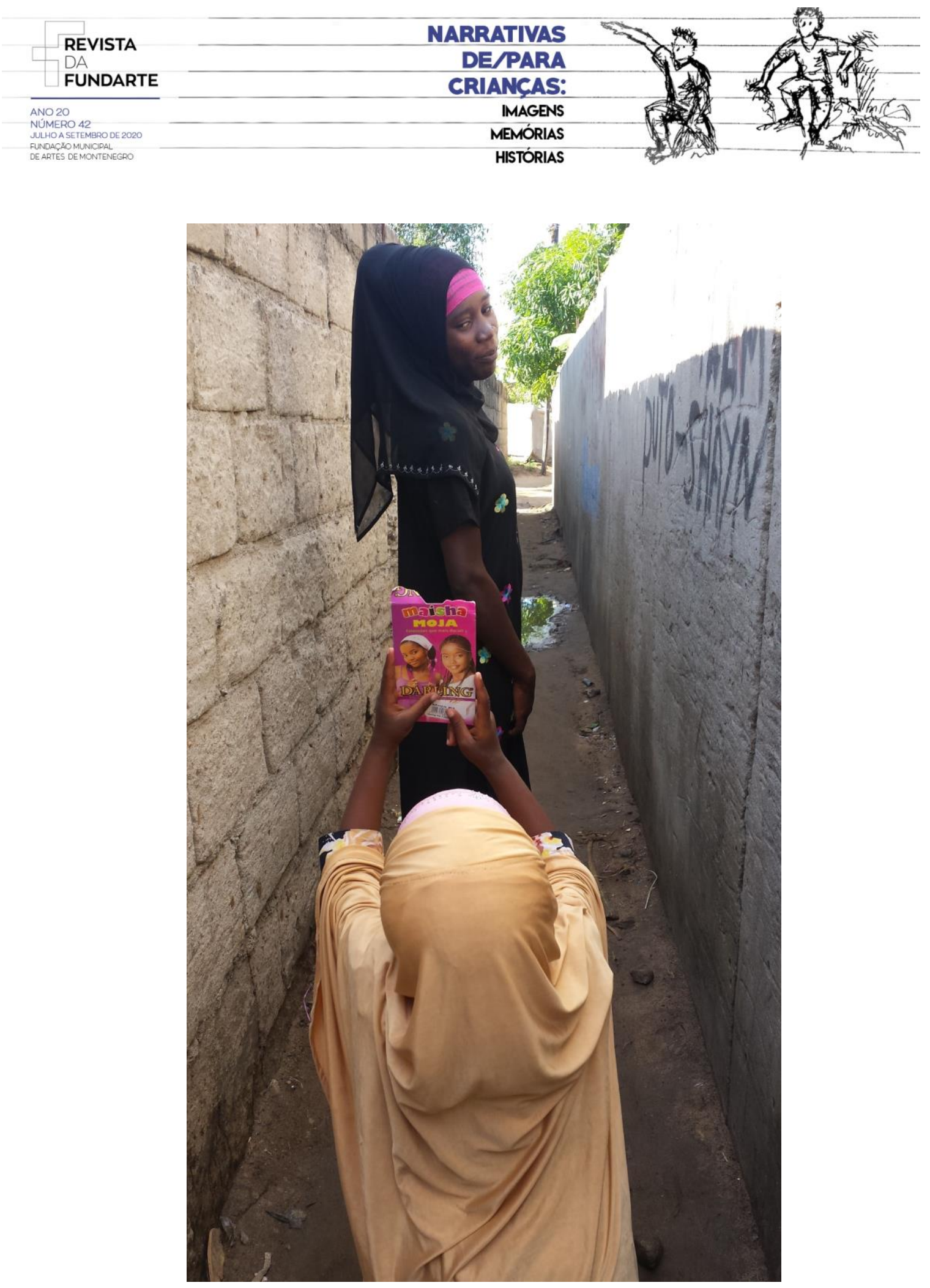

Vamos lá tirar foto com meu telefone (por Manzura e Luna)

E o tempo da gente, como é que se faz? Se quando ganha corpo, acaba em matéria...

O tempo da gente é a gente quem faz

Que tempo que se tem?

PASTORE, Marina Di Napoli. O tempo do brincar: narrativas visuais a partir de experiência etnográfica. Revista da FUNDARTE. Montenegro, p.01-18, ano 26, oㅡ 42, julho/setembro de 2020.

Disponível em: http://.seer.fundarte.rs.gov.br/index.php/RevistadaFundarte/index> 30 de setembro de 2020 

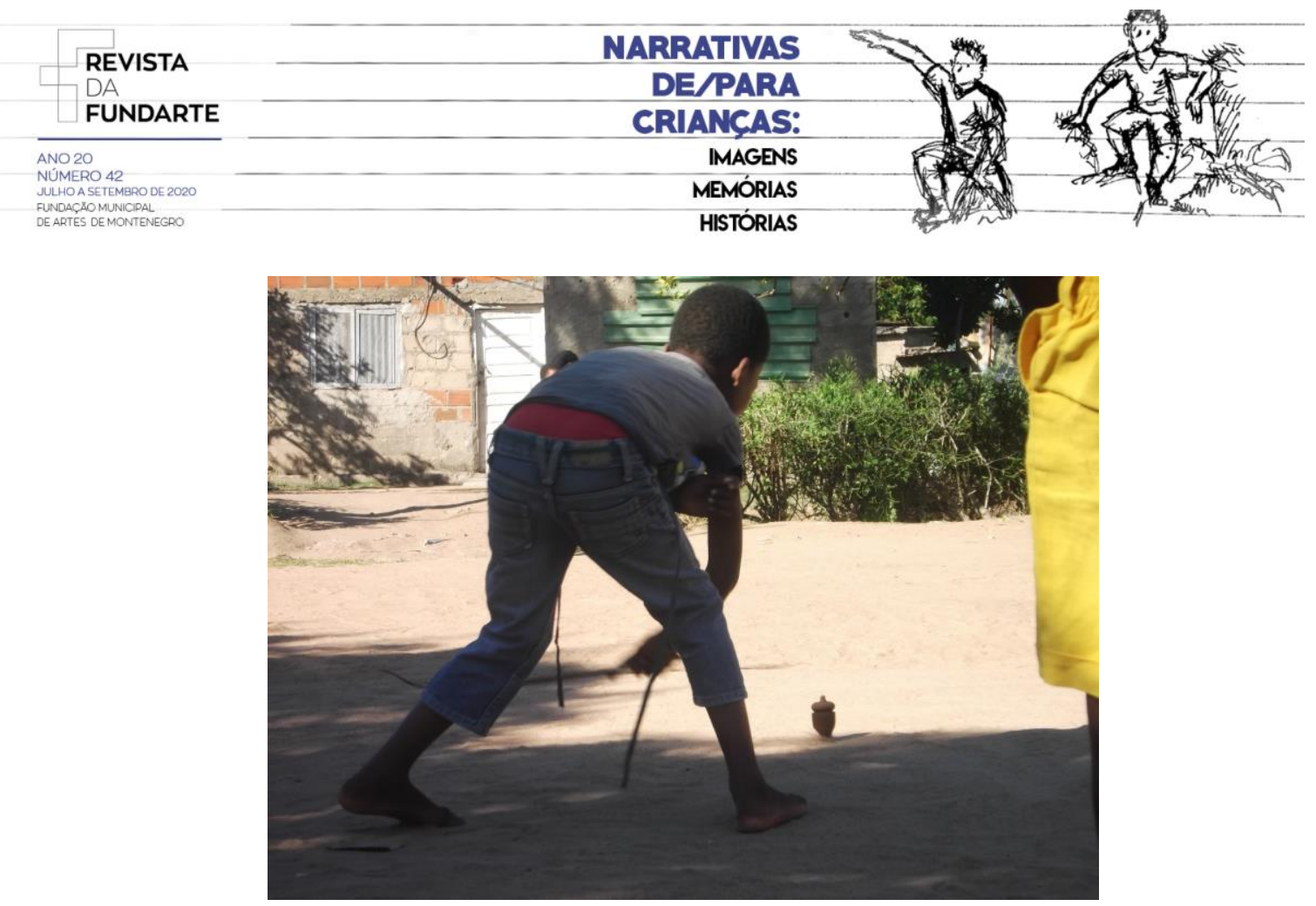

Txindizi (por Captino)

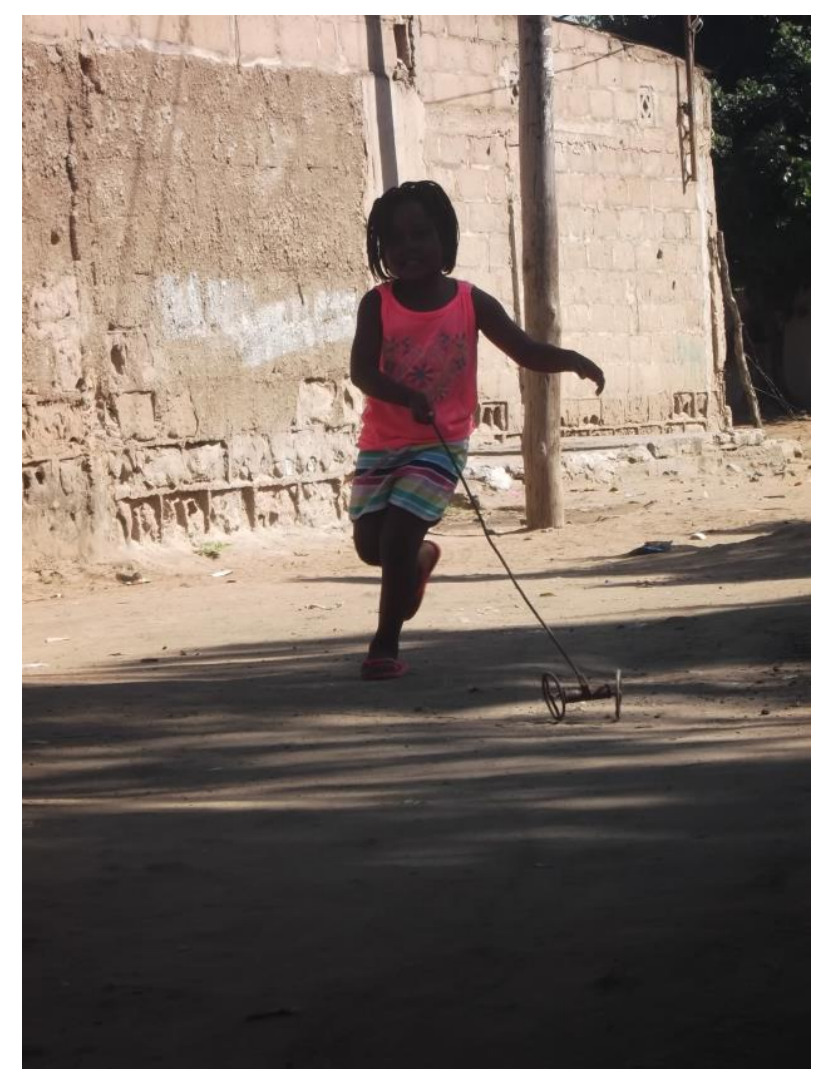

Sai da frente, mana Marina! (por Shelsia)

PASTORE, Marina Di Napoli. O tempo do brincar: narrativas visuais a partir de experiência etnográfica. Revista da FUNDARTE. Montenegro, p.01-18, ano 26, oㅡ 42, julho/setembro de 2020.

Disponível em: http://.seer.fundarte.rs.gov.br/index.php/RevistadaFundarte/index> 30 de setembro de 2020 


REVISTA
DA
FUNDARTE

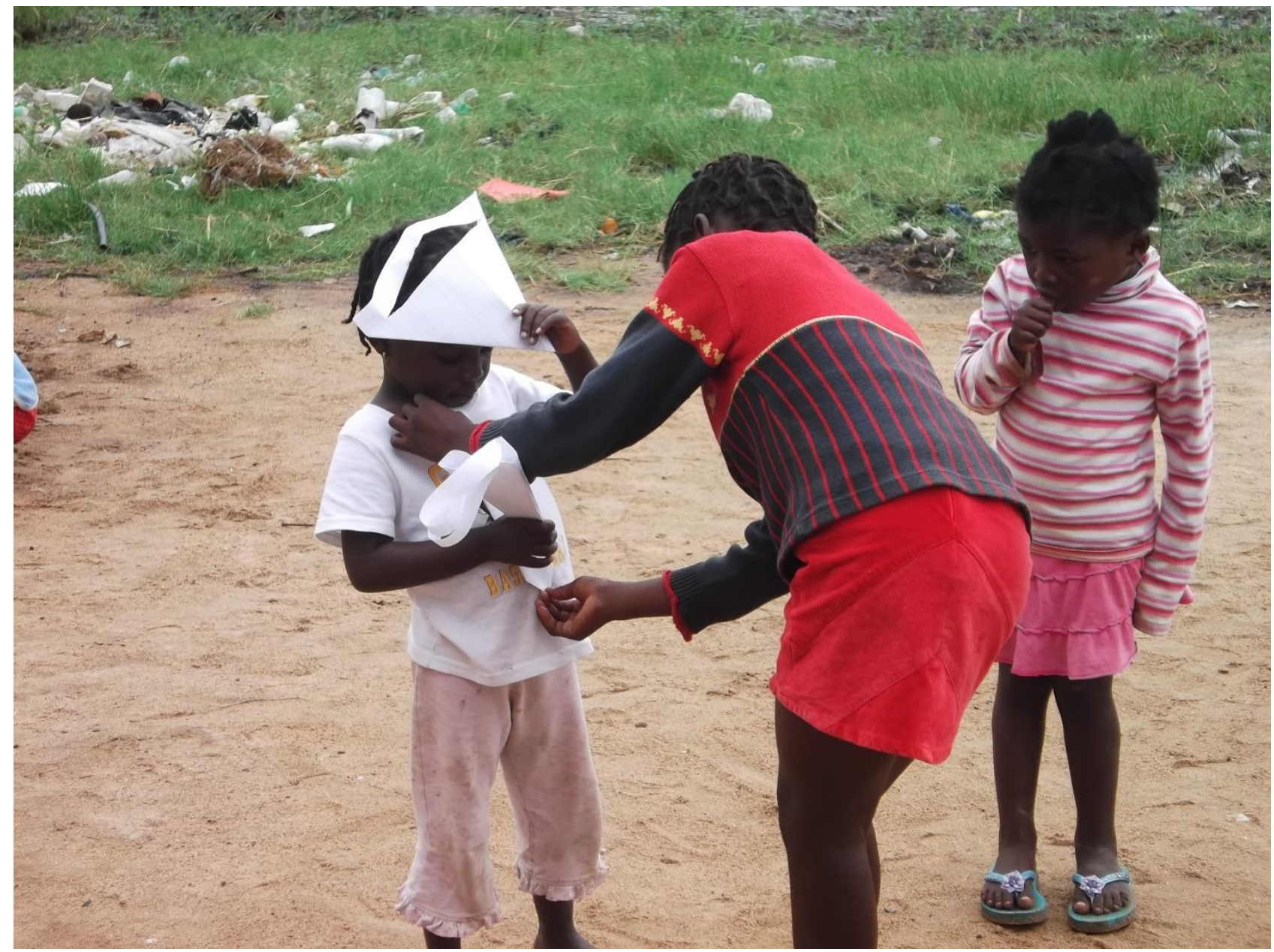

Somos soldados! (por Margarida)

O tempo de estar aberto...

...De correr...

... De observar...

De brincar.

É o tempo do riso, o tempo do sol, o tempo do vento.

PASTORE, Marina Di Napoli. O tempo do brincar: narrativas visuais a partir de experiência etnográfica. Revista da FUNDARTE. Montenegro, p.01-18, ano 26, no 42, julho/setembro de 2020.

Disponível em: http://.seer.fundarte.rs.gov.br/index.php/RevistadaFundarte/index> 30 de setembro de 2020 

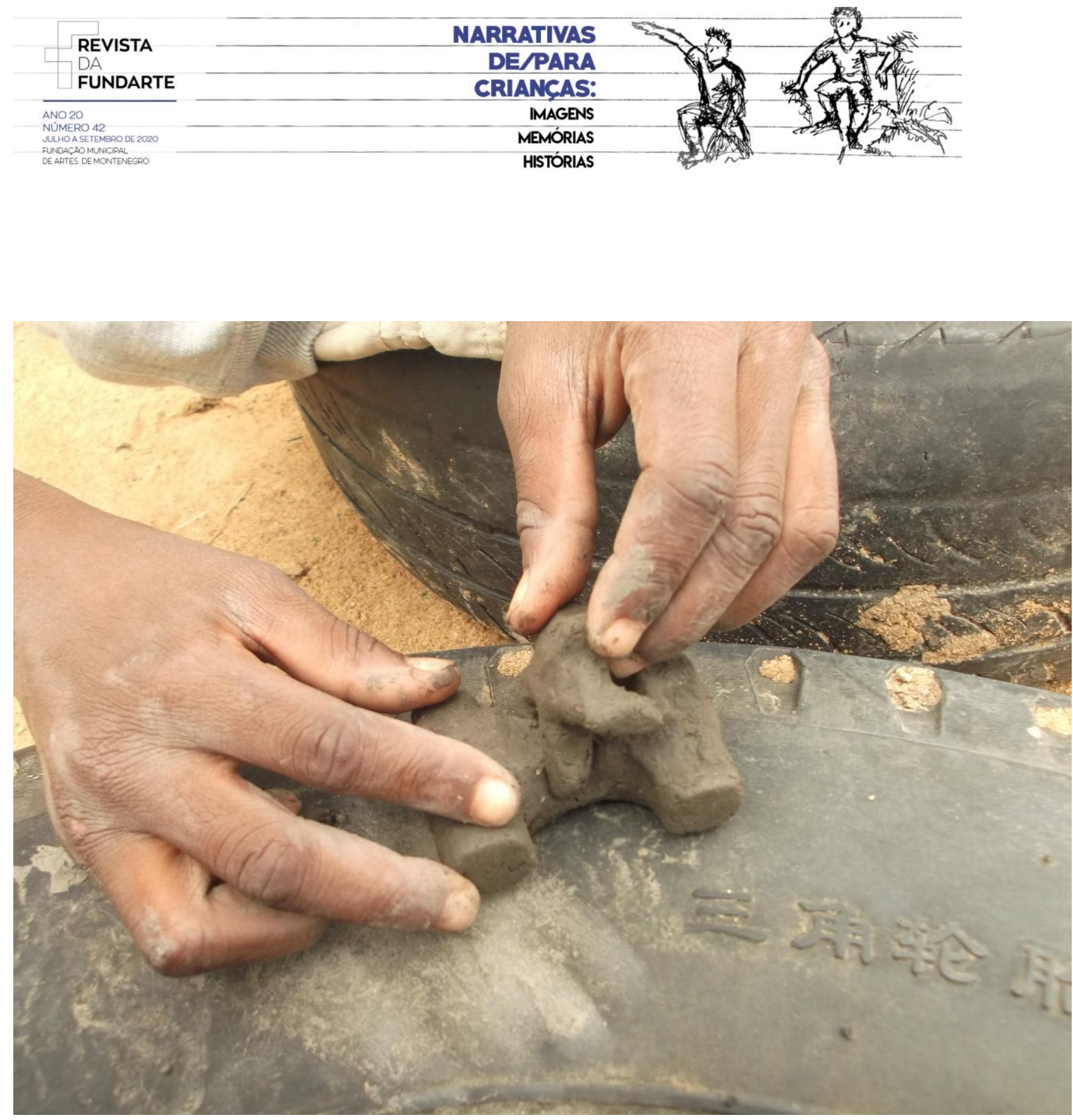

Essa és tu, na sua mota (por Félix)

PASTORE, Marina Di Napoli. O tempo do brincar: narrativas visuais a partir de experiência etnográfica. Revista da FUNDARTE. Montenegro, p.01-18, ano 26, № 42, julho/setembro de 2020.

Disponível em: http://.seer.fundarte.rs.gov.br/index.php/RevistadaFundarte/index> 30 de setembro de 2020 


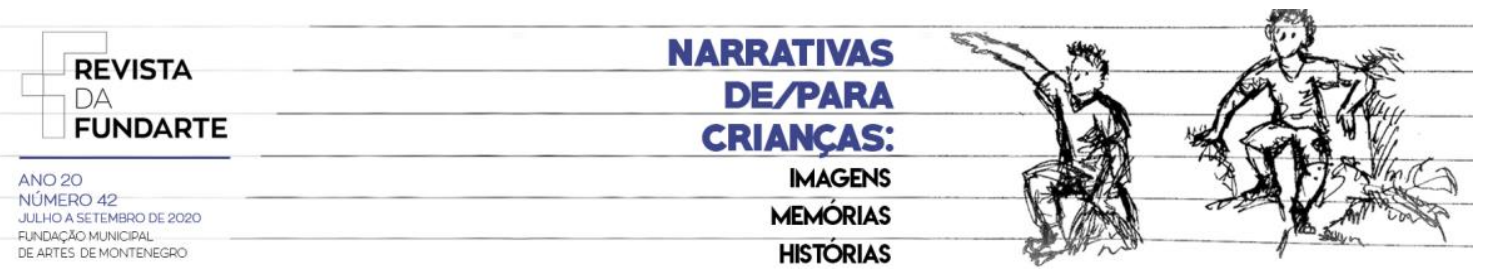
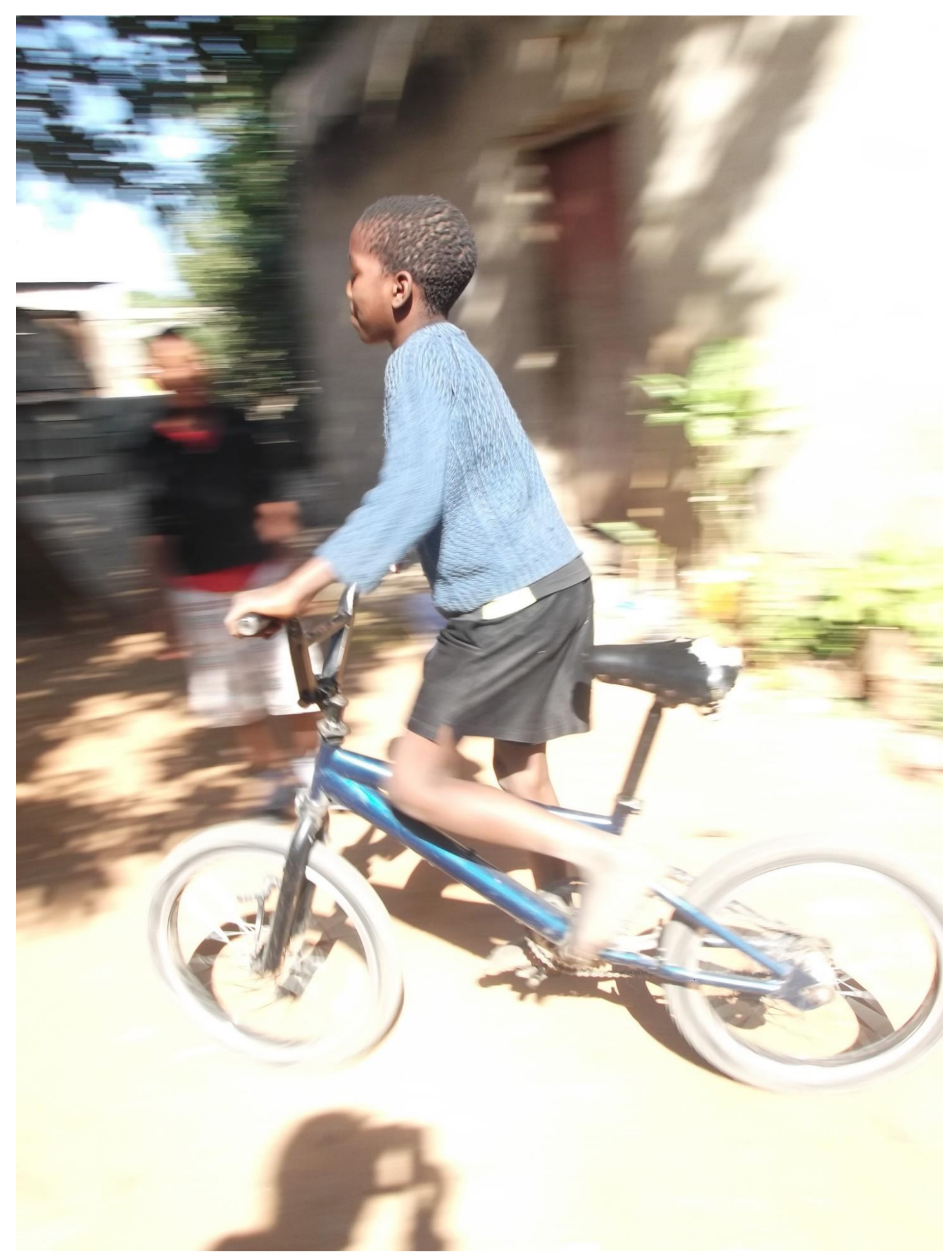

Brincamos na bicicleta (por Beni)

Porque brincar, camaradas, é uma forma de ganhar o(s) mundo(s)

PASTORE, Marina Di Napoli. O tempo do brincar: narrativas visuais a partir de experiência etnográfica. Revista da FUNDARTE. Montenegro, p.01-18, ano 26, oํ 42, julho/setembro de 2020.

Disponível em: http://.seer.fundarte.rs.gov.br/index.php/RevistadaFundarte/index> 30 de setembro de 2020 


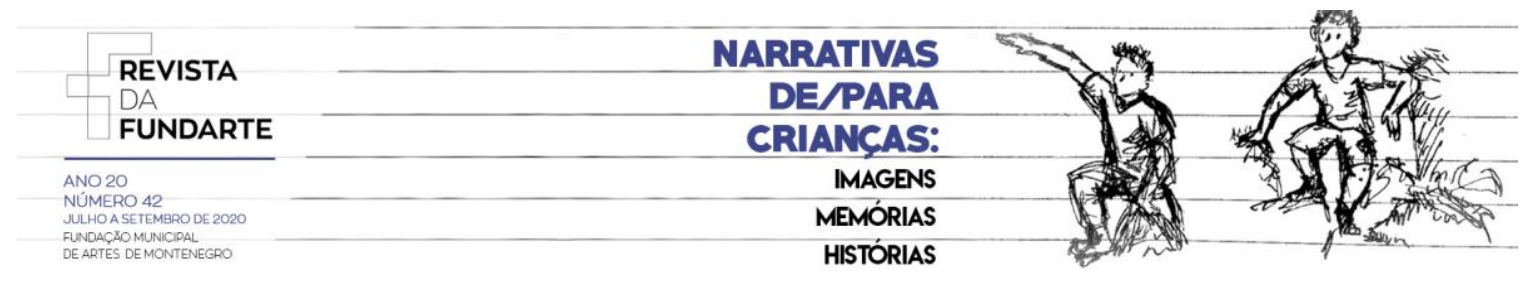

\section{Referências:}

CASCUDO, L. C. Dicionário do folclore brasileiro. 10. ed. São Paulo: Global, 2001.

COLONNA, E. "Eu é que fico com minha irmã". Vida quotidiana das crianças na periferia de Maputo. Tese de doutoramento em Estudos da Criança. Especialidade em Sociologia da Infância. 2012. Visualizado em https://repositorium.sdum.uminho.pt/bitstream/1822/20793/1/Elena\%20Colonna.pdf. Acesso em outubro de 2013.

PASTORE, M. D. N. "Sim! Sou criança eu": dinâmicas de socialização e universos infantis em uma comunidade moçambicana. Dissertação de mestrado em Terapia Ocupacional. Universidade Federal de São Carlos. Programa de Pós-Graduação em Terapia Ocupacional, 2015.

SOARES, N. F.; SARMENTO, M. J.; TOMÁS, C. Investigação da infância e crianças como investigadoras: metodologias participativas dos mundos sociais das crianças. Revista Nuances: estudos sobre educação. UNESP - Presidente Prudente, vol. 12, ํo 13: 49-64, 2005.

Agradecimentos: agradeço a todas as crianças parcerias e co-autoras desta pesquisa, sem a qual nada disso teria sentido. Kanimambo Felix, Januar, Kanguela, Gina, Manelito, Manzura, Shelsia, Beni, Nhanguito, e a todas as outras. etnográfica. Revista da FUNDARTE. Montenegro, p.01-18, ano 26, № 42, julho/setembro de 2020. 